\title{
Reactogenicity of COVID-19 vaccine in hemodialysis patients: a single-center retrospective study
}

Gaetano Alfano ${ }^{1,2^{*}}$, Niccolò Morisi ${ }^{3 *}$, Francesco Fontana ${ }^{1}$, Roberta Scarmignan ${ }^{3}$, Laura Tonelli ${ }^{3}$, Camilla Ferri $^{3}$, Martina Montani ${ }^{3}$, Silvia Giovanella $^{2,3}$, Giulia Ligabue ${ }^{3}$ Giacomo Mori $^{2}$, Erica Franceschini ${ }^{4}$, Giovanni Guaraldi ${ }^{4}$, Gianni Cappelli ${ }^{3}$, Riccardo Magistroni ${ }^{1,3}$, Gabriele Donati ${ }^{1,3}$

1 Nephrology, Dialysis and Transplant Unit, University Hospital of Modena, Modena, Italy

2 Clinical and Experimental Medicine Ph.D. Program, University of Modena and Reggio Emilia, via del Pozzo 71, 41124 Modena, Italy

3 Surgical, Medical and Dental Department of Morphological Sciences, Section of Nephrology, University of Modena and Reggio Emilia, via del Pozzo 71, 41124 Modena, Italy

4 Clinic of Infectious Diseases, University Hospital of Modena, Modena, Italy

* both authors contributed equally as first author

\section{Corresponding author:}

Gaetano Alfano, MD

Surgical, Medical and Dental Department of Morphological Sciences, Section of Nephrology, University Hospital of Modena and Reggio Emilia, via del Pozzo, 71

41124 - Modena (Italy)

E-mail:gaetano.alfano@unimore.it

ORCID: 0000-0003-0591-8622

\section{Short title}

Reactogenicity of mRNA-1273 vaccine in HD patients 
medRxiv preprint doi: https://doi.org/10.1101/2021.11.21.21266561; this version posted January 5, 2022. The copyright holder for this preprint (which was not certified by peer review) is the author/funder, who has granted medRxiv a license to display the preprint in perpetuity.

All rights reserved. No reuse allowed without permission.

\section{Authorship credit}

Conception: Niccolò Morisi, Gaetano Alfano

Collection of data: Camilla Ferri, Martina Montani, Niccolò Morisi,

Analysis and interpretation of data: Gaetano Alfano, Francesco Fontana

Drafting the article: Roberta Scarmignan, Laura Tonelli, Camilla Ferri, Martina Montani, Silvia

Giovanella, Giulia Ligabue, Giacomo Mori

Intellectual Contribution: Francesco Fontana, Erica Franceschini

Revising the article: Gianni Cappelli, Giovanni Guaraldi, Riccardo Magistroini, Gabriele Donati Approval of the version to be published: all authors

\section{Conflicts of interest}

All the authors have declared no competing interest

\section{Funding}

This study was not funded

\section{Acknowledgments}

Special thanks are due to the nephrologists and nurses who managed the vaccination of hemodialysis patients within our dialysis unit.

Text word count: 1989; Abstract word count: 284

Number of references: 18; Number of tables: 3; Number of Figure:3

\section{Keywords}

COVID-19; mRNA-1273; safety; vaccine; hemodialysis; HD; side effects; SARS-COV-2; 
medRxiv preprint doi: https://doi.org/10.1101/2021.11.21.21266561; this version posted January 5, 2022. The copyright holder for this preprint (which was not certified by peer review) is the author/funder, who has granted medRxiv a license to display the preprint in perpetuity.

All rights reserved. No reuse allowed without permission.

\section{Abstract \\ Introduction}

Some hemodialysis patients are reluctant to COVID-19 for the development of adverse events (AEs). The aim of this study was to verify the safety of mRNA-1273 vaccine in hemodialysis patients.

\section{Methods}

We conducted a retrospective analysis of in-center hemodialysis patients who underwent mRNA1273 vaccine from March $1^{\text {st }}$ to April $30^{\text {th }}, 2021$. All AEs occurring after the first and the second doses were collected and classified as local or systemic.

\section{Results}

Overall, 126 patients on chronic maintenance dialysis without a prior COVID-19 diagnosis were vaccinated with two doses of mRNA-1273 vaccine. Mean age was 68 (IQR, 54,7-76) years and $53.6 \%$ of patients were aged $\geq 65$ years. During the observational period of 68 (IQR, 66-70) days, AEs occurred in $57.9 \%$ and $61.9 \%$ of patients after the first dose and second dose, respectively. The most common AEs were: injection-site pain (61.9\%), erythema (4.8\%), itching (4.8\%), swelling (16.7\%), axillary swelling/tenderness $(2.4 \%)$, fever $(17.5 \%)$ headache $(7.9 \%)$, fatigue $(23.8 \%)$, myalgia (17.5\%), arthralgia (12.7\%), dyspnoea (2.4\%), nausea/vomiting (7.1\%), diarrhoea (5.6\%), shivers (4\%) and vertigo (1.6\%).

The rates of local AEs were similar after the first and second doses $(\mathrm{P}=0.8)$, whereas systemic AEs occurred more frequently after the second dose $(\mathrm{P}=0.001)$. Fever $(\mathrm{P}=0.03)$, fatigue $(\mathrm{P}=0.02)$ and nausea/vomiting $(\mathrm{P}=0.03)$ were significantly more frequent after the second dose of the vaccine. There were no age-related differences in the rate of AEs. Overall, vaccine-related AEs in hemodialysis patients seem to be lower than in the general population.

\section{Conclusion}


medRxiv preprint doi: https://doi.org/10.1101/2021.11.21.21266561; this version posted January 5, 2022. The copyright holder for this preprint (which was not certified by peer review) is the author/funder, who has granted medRxiv a license to display the preprint in perpetuity.

All rights reserved. No reuse allowed without permission.

RNA-1273 vaccine was associated with the development of transient AEs after the first (57.9\%) and second doses (61.9\%) in patients on chronic maintenance hemodialysis. Systemic AEs were more common after the second dose. Overall, all AEs lasted for a few days, without any apparent sequelae. 
medRxiv preprint doi: https://doi.org/10.1101/2021.11.21.21266561; this version posted January 5, 2022. The copyright holder for this preprint (which was not certified by peer review) is the author/funder, who has granted medRxiv a license to display the preprint in perpetuity.

All rights reserved. No reuse allowed without permission.

\section{Introduction}

Coronavirus Disease-2019 (COVID-19) is a novel infectious disease that carries a high burden of mortality and morbidity worldwide ${ }^{1}$. In the absence of a specific treatment for COVID-19, vaccination is currently the most effective strategy to prevent this disease ${ }^{2}$. Highly effective vaccines against SARS-CoV-2 infection have been developed and administered globally for a fullvaccine coverage strategy. To attain the goal of reducing COVID-19 related mortality, current policies prioritized vaccination of frail populations including patients on maintenance hemodialysis ${ }^{3}$. This group of patients is particularly at risk of COVID-19 because includes subjects with advanced age and compromised immunity ${ }^{4}$, moreover, the thrice-a-week in-center haemodialytic treatment carries a high risk of cluster infection ${ }^{5,6}$. For these reasons, the immunization of hemodialysis patients has been recognized as a public health priority worldwide and a mass vaccination with RNA-platform such as mRNA-1273 vaccine (previously known as vaccine Moderna) has been soon conducted after the release of regulatory agencies' authorization. Safety and efficacy of mRNA-1273 vaccine has been tested in phase III clinical trial (ClinicalTrials.gov n. NCT04470427) recruiting 30.351 participants. The promising results showed 94.1\% efficacy at preventing Covid-19 illness, including severe disease . $^{7,8}$.

Vaccine-related adverse events (AEs) were usually mild or moderate in intensity and resolved within a few days ${ }^{7}$. The most commonly AEs were injection-site pain (92\%), fatigue (70\%), headache $(64.7 \%)$, myalgia $(61.5 \%)$, arthralgia $(46.4 \%)$, shivers $(45.4 \%)$, nausea/vomiting $(23 \%)$, axillary swelling/tenderness (19.8\%), fever (15.5\%), swelling (14.7\%) and erythema (10\%).

Nevertheless, the fear of developing vaccine-related symptoms led patients to deny vaccination or additional booster doses. A recent nationwide vaccine acceptability survey conducted in 150 facilities in the United States reported that about half of patients who were vaccine-hesitant expressed concerns about vaccine-side effects ${ }^{9}$. This perception is contradicted by recent vaccine 
medRxiv preprint doi: https://doi.org/10.1101/2021.11.21.21266561; this version posted January 5, 2022. The copyright holder for this preprint (which was not certified by peer review) is the author/funder, who has granted medRxiv a license to display the preprint in perpetuity.

All rights reserved. No reuse allowed without permission.

safety data reporting the incidence of severe AEs was similar in mRNA-1273 (1.0\%, 147 events)

and placebo $\left(1.0 \%, 153\right.$ events) groups during the study period ${ }^{10}$. However, no studies have been conducted to evaluate the reactogenicity of the mRNA-1273 vaccine in patients on maintenance dialysis. To inform public health and clinical practice, we investigated the safety of the mRNA1273 vaccine in a cohort of hemodialysis patients.

\section{Methods}

Study population included patients aged $\geq 18$ years on chronic maintenance hemodialysis at the University Hospital of Modena, Italy. Anti-SARS-CoV-2 vaccination was performed in all patients without a prior COVID-19 diagnosis and without signs of ongoing infection who provided written consent from March $24^{\text {th }}$ to April $30^{\text {th }}, 2021$.

All charts of these patients were reviewed retrospectively.

This study has been authorized by the local Ethical Committee of Emilia Romagna (n. 839/2020).

RNA-1273 vaccine contains a molecule of messenger RNA (mRNA) carrying instructions encoding the spike protein, a protein on the surface of the SARS-CoV-2 virus which the virus needs to enter the body's cells. Once the human cells have produced the spike protein, the immune system recognizes this protein as foreign and produces antibodies and activates $\mathrm{T}$ cells to attack it.

This vaccine was found to be safe and efficacious (94.1\%) in preventing symptomatic, laboratoryconfirmed COVID-19 in a large, randomized-controlled trial ${ }^{7}$ and subsequent observational studies $^{11,12}$. To facilitate its availability and its use, Food and Drug Administration (FDA) and European Medicine Agency issued an emergency use authorization in the United States (December 2020) and Europe (January 2020), respectively ${ }^{10,13}$. 
medRxiv preprint doi: https://doi.org/10.1101/2021.11.21.21266561; this version posted January 5, 2022. The copyright holder for this preprint (which was not certified by peer review) is the author/funder, who has granted medRxiv a license to display the preprint in perpetuity.

All rights reserved. No reuse allowed without permission.

In our patients RNA-1273 vaccine was administered as two intramuscular injections, 28 days apart, by dialysis nurses. Injection of the vaccines was provided 30 minutes before the start of the dialysis session on the non-arteriovenous fistula arm. To optimize the number of vaccine doses, some patients were vaccinated at the end of the dialysis session if no hemodialysis-associated complications (hypotension, nausea, vomiting) occurred during the treatment. Patients were monitored on-site for at least 15 minutes after the vaccine injection. Subjects who had severe allergic reactions or any type of immediate allergic reaction to drugs were monitored for at least 30 minutes. Anticoagulant therapy was left unchanged when vaccination was performed before the dialysis session.

Adverse events

AEs were considered related to the vaccine when they occurred soon after the vaccination. The duration of the side effects was counted as a whole 24 hour period. Fever was classified as a symptom only when body temperature was above $37.5^{\circ} \mathrm{C}$.

\section{Statistical analysis}

Baseline characteristics were described using median and interquartile range (IQR) or mean and standard deviation (SD). The percentage was used to describe categorical variables. The Student's t-test and chi-square or Fisher's test were used to compare continuous compare and categorical variables between groups, respectively.

A P value of $<0.05$ was considered statistically significant. All statistical analyses were performed using SPSS 24® statistical software.

\section{Results}


medRxiv preprint doi: https://doi.org/10.1101/2021.11.21.21266561; this version posted January 5, 2022. The copyright holder for this preprint (which was not certified by peer review) is the author/funder, who has granted medRxiv a license to display the preprint in perpetuity.

All rights reserved. No reuse allowed without permission.

RNA-1273 vaccine was administered to 126 patients on chronic maintenance hemodialysis.

Baseline characteristics of participants are shown in Table 1. Median age was 68 (IQR, 54.7-76)

years and more than half of patients $(53.6 \%)$ were aged $\geq 65$ years. Seventy-one patients were male $(53.6 \%)$ and the majority of the patients were of Caucasian origin (87.3\%). Median observation time from the second dose of the vaccine to the end of the study was 68 (IQR, 66-70) days.

\section{First dose}

After the first dose of RNA-1273 vaccine, local AEs occurred in $68(53,9 \%)$ hemodialysis patients whereas systemic AEs in only 20 of them (15.8\%).

As shown in Figure 1A, the most common local symptoms were injection-site pain $(50.7 \%)$ followed by local swelling (9.5\%), erythema (3.1\%) and itching (3.1\%).

Fatigue $(11.1 \%)$, myalgia $(7.9 \%)$ fever $(5.1 \%)$ and arthralgia $(5.1 \%)$ were the most common systemic AEs experienced by hemodialysis patients.

\section{Second dose}

The second dose was associated with local (51.6\%) and systemic (34.1\%) symptoms. The most common local AEs were site injection-site pain (47.6\%) followed by local swelling (8.7\%) and itching (3.9\%). Systemic AEs included fatigue (22.2\%), fever (14.2\%) and myalgia (15.07\%) (Figure 1B).

\section{Difference between first and second dose}

Time elapsed from the first dose and second dose was 28 (IQR, 28-28) days. No differences were found in terms of local AEs between the first and second doses of vaccine $(\mathrm{P}=0.8)$, whereas the second dose was significantly associated with more systemic AEs than the first dose. $(\mathrm{P}=0.001)$. 
medRxiv preprint doi: https://doi.org/10.1101/2021.11.21.21266561; this version posted January 5, 2022. The copyright holder for this preprint (which was not certified by peer review) is the author/funder, who has granted medRxiv a license to display the preprint in perpetuity.

All rights reserved. No reuse allowed without permission.

As detailed in Table 2 and Figure 2, fever $(\mathrm{P}=0.033)$, fatigue $(\mathrm{P}=0.02)$ and nausea/vomiting $(\mathrm{P}=0.03)$ occurred more frequently after the second dose of vaccine.

Seventy-three (57.9\%) patients reported at least one AE after the first dose and $78(61.9 \%)$ at least one $\mathrm{AE}$ after the second dose.

Analysis of the data detected statistically significant differences in duration of symptoms between the first and second doses regarding axillary swelling/tenderness $(\mathrm{P}=0.07)$ and diarrhea $(\mathrm{P}=0.02)$. In both cases, these symptoms lasted longer after the second dose of the vaccine (Table 3). No differences in terms of symptoms were found between younger participants (18 to <65 years of age) and older participants ( $\geq 65$ years of age) (Figure 3 A e B).

\section{Completed vaccination cycle}

Overall, $71.4 \%$ of patients experienced vaccine-related AEs. In particular, the most commonly reported AEs were: injection-site pain (61.9\%), erythema (4.8\%), itching (4.8\%), swelling (16.7\%), axillary swelling/tenderness $(2.4 \%)$, fever (17.5\%) headache (7.9\%), fatigue $(23.8 \%)$, myalgia (17.5\%), arthralgia (12.7\%), dyspnoea (2.4\%); nausea/ vomiting (7.1\%), diarrhoea (5.6\%), shivers (4\%) and vertigo (1.6\%).

Management of AEs occurred in outpatient settings without the need for hospitalization.

Comparison of these findings with the data of phase III randomized trial ${ }^{7,8}$ showed that hemodialysis patients reported a lower rate of AE compared to the general population after the first dose $(57.9 \%$ vs. $84.2 \%)$ and the second dose (61.9\% vs. $88.6 \%)$.

Only one patient had herpes zoster reactivation after one week from the first dose. It healed after the administration of specific antiviral therapy.

\section{Discussion}


medRxiv preprint doi: https://doi.org/10.1101/2021.11.21.21266561; this version posted January 5, 2022. The copyright holder for this preprint (which was not certified by peer review) is the author/funder, who has granted medRxiv a license to display the preprint in perpetuity.

All rights reserved. No reuse allowed without permission.

mRNA-1273 vaccine is an effective tool of our armamentarium to prevent the severe consequences of COVID-19. This type of vaccine, based on RNA platform technology, has shown short- and long-term safety and efficacy in preventing symptomatic, laboratory-confirmed COVID-19 in a phase III trial ${ }^{7,8}$ and post-marketing studies ${ }^{11,12}$. Similar to other vaccines, RNA-1273 is associated with mild-moderate local and systemic AEs. Generally, these side effects developed within a few days after vaccination as a sign of an effective immune response against the foreign protein.

At present, the reactogenicity of mRNA-1273 of vaccine is unknown in the hemodialysis population, given their exclusion from the pre-marketing clinical trial. The low response rate to the vaccine and the high rate of COVID-19 infection after vaccination in the hemodialysis population, ${ }^{17,18}$ supports the hypothesis that the rate of AEs might be even lower than the general population because this cohort of patients is believed to have defects in humoral and cellular immunity.

In our study, we found that the mRNA-1273 vaccine was associated with local and systemic AEs in patients on in-center maintenance hemodialysis. About three-quarters (71.4\%) of our patients experienced any type of AEs after the completion of the dual-dose SARS-CoV-2 vaccination. The rate of local reactions was higher than systemic AEs for both doses, without any statistically significant differences between the first and the second doses.

Injection-site pain, fatigue and myalgia were the most commonly reported side effects reported by our patients. Overall, these symptoms were transient and recovery occurred without sequelae, on average, within 2 days from the injection. As expected, the immune system of our patients, sensitized to the foreign protein, had a more robust response with the delivery of the second dose. A higher rate of AEs including fever (14.2\% vs 5.1\%), fatigue (22.2\% vs $11.1 \%)$, myalgia (11.1\% vs $22.2 \%)$, arthralgia (11.1\% vs 5.1\%) and headache (6.3\%vs $2.3 \%)$ was indeed observed after the administration of the second. 
medRxiv preprint doi: https://doi.org/10.1101/2021.11.21.21266561; this version posted January 5, 2022. The copyright holder for this preprint (which was not certified by peer review) is the author/funder, who has granted medRxiv a license to display the preprint in perpetuity.

All rights reserved. No reuse allowed without permission.

We also investigate the age-related reactogenicity of RNA-1273 in our patients, because this vaccine showed a slightly lower frequency injection-site and systemic AEs in older participants ( $\geq 65$ years of age) compared to younger participants (18 to $<65$ years of age). Our findings showed the rate and the duration of AEs were similar between the younger (18 to 64 years) and older (6584 years) hemodialysis patients. The reasons why the RNA-1273 vaccine elicited no age-related differences in the development of AEs are unclear. Likely, the burden of immunodepression induced by ESRD heavily affects the immune system of hemodialysis patients, and minimizes the differences due to aging.

Taking all together, mild-moderate vaccine-related AEs are frequent in hemodialysis patients and, consequently, healthcare workers in the dialysis units must learn to cope with them. Generally, the detection of severe systemic symptoms (i.e., fever, dyspnoea, nausea or vomiting) requires immediate attention because these symptoms are common to a large spectrum of conditions including infections, fluid overload, and electrolytes disturbance as well as COVID-19. Thus, we suggest a prudential behavior in hemodialysis patients presenting with fever and fatigue after vaccination, in order to prevent a potential COVID-19 outbreak in the dialysis unit.

Lastly, we noted a low rate of AEs of SARS-CoV-2 vaccine in hemodialysis patients after the first dose (57.9\% vs. $84.2 \%)$ and second dose (61.9\% vs. $88.6 \%)$ when compared to the general population. This low-level reactogenicity should be partially due to the burden of comorbidities, advanced age and suboptimal immune response of hemodialysis patients against SARS-CoV-2 antigen. In support of this theory, there is evidence that the effectiveness of hepatitis $\mathrm{B}^{16}$, influenza $^{17}$ and SARS-CoV-2 vaccination ${ }^{18,15}$ is reduced in this frail population. 
Some limitations of the study should be enunciated. The retrospective nature of the analysis and the small sample size could lead to unintended bias in the correct estimation of vaccine-related AEs. Measure of AEs magnitude was not collected in our patients, albeit none required acute hospital inpatient care after the administration of vaccine. Lastly, our study provides key information for healthcare workers to plan active surveillance on hemodialysis patients.

\section{Conclusion}

RNA-1273 vaccine was associated with the development of transient AEs after the first (57.9\%) and second dose $(61.9 \%)$ of vaccine in patients on chronic maintenance dialysis. Systemic AEs were more common after the second dose than the first dose of vaccine. The duration of these symptoms lasted for a few days, without any apparent consequences. These data confirm the safety of the RNA-1273 vaccine in hemodialysis patients and support the promotion of COVID19 vaccination in hesitant patients. 


\section{Bibliography}

1. COVID-19 Map. Johns Hopkins Coronavirus Resource Center. Accessed November 9, 2021. https://coronavirus.jhu.edu/map.html

2. Lopez Bernal J, Andrews N, Gower C, et al. Effectiveness of Covid-19 Vaccines against the B.1.617.2 (Delta) Variant. N Engl J Med. 2021;385(7):585-594. doi:10.1056/NEJMoa2108891

3. Combe C, Kirsch AH, Alfano G, et al. At least 156 reasons to prioritize COVID-19 vaccination in patients receiving in-centre haemodialysis. Nephrol Dial Transplant Off Publ Eur Dial Transpl Assoc - Eur Ren Assoc. 2021;36(4):571-574. doi:10.1093/ndt/gfab007

4. Lamarche C, Iliuta IA, Kitzler T. Infectious Disease Risk in Dialysis Patients: A Transdisciplinary Approach. Can J Kidney Health Dis. 2019;6:2054358119839080. doi:10.1177/2054358119839080

5. Li SY, Tang YS, Chan YJ, Tarng DC. Impact of the COVID-19 pandemic on the management of patients with end-stage renal disease. J Chin Med Assoc JCMA. 2020;83(7):628-633. doi:10.1097/JCMA.0000000000000356

6. Cohen DE, Sibbel S, Marlowe G, et al. Antibody Status, Disease History, and Incidence of SARS-CoV-2 Infection Among Patients on Chronic Dialysis. J Am Soc Nephrol JASN. 2021;32(8):1880-1886. doi:10.1681/ASN.2021030387

7. Baden LR, El Sahly HM, Essink B, et al. Efficacy and Safety of the mRNA-1273 SARS-CoV2 Vaccine. $N$ Engl J Med. 2021;384(5):403-416. doi:10.1056/NEJMoa2035389

8. El Sahly HM, Baden LR, Essink B, et al. Efficacy of the mRNA-1273 SARS-CoV-2 Vaccine at Completion of Blinded Phase. N Engl J Med. 2021;385(19):1774-1785. doi:10.1056/NEJMoa2113017

9. Garcia P, Montez-Rath ME, Moore H, et al. SARS-CoV-2 Vaccine Acceptability in Patients on Hemodialysis: A Nationwide Survey. J Am Soc Nephrol. 2021;32(7):1575-1581. doi:10.1681/ASN.2021010104 
medRxiv preprint doi: https://doi.org/10.1101/2021.11.21.21266561; this version posted January 5, 2022. The copyright holder for this preprint

(which was not certified by peer review) is the author/funder, who has granted medRxiv a license to display the preprint in perpetuity.

All rights reserved. No reuse allowed without permission.

10. spikevax-previously-covid-19-vaccine-moderna-epar-medicine-overview_en.pdf. Accessed November 7, 2021. https://www.ema.europa.eu/en/documents/overview/spikevax-previouslycovid-19-vaccine-moderna-epar-medicine-overview_en.pdf

11. Thompson MG, Burgess JL, Naleway AL, et al. Interim Estimates of Vaccine Effectiveness of BNT162b2 and mRNA-1273 COVID-19 Vaccines in Preventing SARS-CoV-2 Infection Among Health Care Personnel, First Responders, and Other Essential and Frontline Workers — Eight U.S. Locations, December 2020-March 2021. Morb Mortal Wkly Rep. 2021;70(13):495-500. doi:10.15585/mmwr.mm7013e3

12. Pawlowski C, Lenehan P, Puranik A, et al. FDA-authorized mRNA COVID-19 vaccines are effective per real-world evidence synthesized across a multi-state health system. Med $N$ Y . 2021;2(8):979-992.e8. doi:10.1016/j.medj.2021.06.007

13. Commissioner O of the. FDA Approves First COVID-19 Vaccine. FDA. Published August 23, 2021. Accessed November 7, 2021. https://www.fda.gov/news-events/pressannouncements/fda-approves-first-covid-19-vaccine

14. Speer C, Benning L, Töllner M, et al. Neutralizing antibody response against variants of concern after vaccination of dialysis patients with BNT162b2. Kidney Int. 2021;100(3):700702. doi:10.1016/j.kint.2021.07.002

15. Yanay NB, Freiman S, Shapira M, et al. Experience with SARS-CoV-2 BNT162b2 mRNA vaccine in dialysis patients. Kidney Int. 2021;99(6):1496-1498. doi:10.1016/j.kint.2021.04.006

16. Burdick RA, Bragg-Gresham JL, Woods JD, et al. Patterns of hepatitis B prevalence and seroconversion in hemodialysis units from three continents: The DOPPS. Kidney Int. 2003;63(6):2222-2229. doi:10.1046/j.1523-1755.2003.00017.x

17. Gilbertson DT, Unruh M, McBean AM, Kausz AT, Snyder JJ, Collins AJ. Influenza vaccine delivery and effectiveness in end-stage renal disease. Kidney Int. 2003;63(2):738-743. doi:10.1046/j.1523-1755.2003.00787.x

18. Alfano G, Fontana F, Mori G, et al. Seroconversion after COVID-19 vaccine in a dialysis patient on immunosuppressants. Clin Kidney J. 2021;(sfab065). doi:10.1093/ckj/sfab065 
medRxiv preprint doi: https://doi.org/10.1101/2021.11.21.21266561; this version posted January 5, 2022. The copyright holder for this preprint (which was not certified by peer review) is the author/funder, who has granted medRxiv a license to display the preprint in perpetuity.

All rights reserved. No reuse allowed without permission.

Table 1. Demographic and clinical characteristics of hemodialysis patients who underwent RNA-1273 vaccine

\begin{tabular}{|c|c|}
\hline Basal characteristics & $\begin{array}{c}\text { All patients } \\
n=126\end{array}$ \\
\hline Age (yr) & $68(54.7-6)$ \\
\hline (range) & $19-92$ \\
\hline$\geq 65 \mathrm{yr}$ & $71(56.3)$ \\
\hline Males, n. (\%) & $71(56.31)$ \\
\hline \multicolumn{2}{|l|}{ Ethnic origin, n. (\%) } \\
\hline Caucasian & $110(87.3)$ \\
\hline African & $15(11.9)$ \\
\hline Hispanic & $1(0.8)$ \\
\hline \multicolumn{2}{|l|}{ Etiology of ESRD, n. (\%) } \\
\hline Nephrosclerosis & $54(42.9)$ \\
\hline Glomerulonephritis & $26(20.6)$ \\
\hline Diabetes & $14(11.1)$ \\
\hline ADPKD & $4(3.2)$ \\
\hline Nephrotoxic & $4(3.2)$ \\
\hline Pyelonephritis & $4(3.2)$ \\
\hline Interstitial & $3(2.4)$ \\
\hline HIVAN & $2(1.6)$ \\
\hline Others & $10(7.9)$ \\
\hline
\end{tabular}


medRxiv preprint doi: https://doi.org/10.1101/2021.11.21.21266561; this version posted January 5, 2022. The copyright holder for this preprint (which was not certified by peer review) is the author/funder, who has granted medRxiv a license to display the preprint in perpetuity. All rights reserved. No reuse allowed without permission.

\begin{tabular}{|c|r|}
\hline NA & $5(4)$ \\
\hline HD treatment schedule, n. (\%) & \\
\hline 3 times per week & $115(91.2)$ \\
\hline 2 times per week & $7(5.5)$ \\
\hline 4 times per week & $4(3.1)$ \\
\hline Infectious disease, n. $(\%)$ & $3(2.3)$ \\
\hline HBV & $3(2.3)$ \\
\hline HCV & $2(1.5)$ \\
\hline HIV & $28(28-28)$ \\
\hline Time elapsed from the first to the second dose of vaccine, day & $68(66-70)$ \\
\hline Follow-up, day & \\
\hline
\end{tabular}

ESRD denotes end-stage renal disease; $\mathrm{HBV}$, hepatitis B virus; $\mathrm{HCV}$, hepatitis $\mathrm{C}$ virus 
medRxiv preprint doi: https://doi.org/10.1101/2021.11.21.21266561; this version posted January 5, 2022. The copyright holder for this preprint (which was not certified by peer review) is the author/funder, who has granted medRxiv a license to display the preprint in perpetuity. All rights reserved. No reuse allowed without permission.

Table 2. Rate of AEs after the first and second dose

\begin{tabular}{lrrrrr}
\hline & \multicolumn{2}{c}{ First dose } & Second dose & p value \\
\hline Any local AR. n. (\%) & 68 & $(53.9)$ & 65 & $(51.5)$ & 0.80 \\
Pain. n. (\%) & 64 & $(50.7)$ & 60 & $(47.6)$ & 0.70 \\
Erythema. n. (\%) & 4 & $(3.1)$ & 4 & $(3.1)$ & $>0.99$ \\
Itching. n. (\%) & 4 & $(3.1)$ & 5 & $(3.9)$ & $>0.99$ \\
Swelling. n. (\%) & 12 & $(9.5)$ & 11 & $(8.7)$ & $>0.99$ \\
Axillary swelling/tenderness*. n. (\%) & 2 & $(1.5)$ & 4 & $(3.1)$ & $>0.99$ \\
& & & & & \\
Any systemic AR. n. (\%) & 20 & $(15.8)$ & $43(34.1)$ & $\mathbf{0 . 0 0 1}$ \\
Fever. n. (\%) & 7 & $(5.1)$ & $18(14.2)$ & $\mathbf{0 . 0 3}$ \\
Headache. n. (\%) & 3 & $(2.3)$ & 8 & $(6.3)$ & 0.21 \\
Fatigue. n. (\%) & 14 & $(11.1)$ & 28 & $(22.2)$ & $\mathbf{0 . 0 2}$ \\
Myalgia. n. (\%) & 10 & $(7.9)$ & 19 & $(15)$ & 0.11 \\
Arthralgia. n. (\%) & 7 & $(5.1)$ & 14 & $(11.1)$ & 0.17 \\
Dispnea. n. (\%) & 2 & $(1.5)$ & 2 & $(1.5)$ & $>0.99$ \\
Nausea/vomiting. n. (\%) & 3 & $(2.3)$ & 7 & $(5.5)$ & $\mathbf{0 . 0 3}$ \\
Diarrhea. n. (\%) & 2 & $(1.5)$ & 5 & $(3.9)$ & 0.44 \\
Chills. n. (\%) & 4 & $(3.1)$ & 4 & $(3.1)$ & $>0.99$ \\
Vertigo. n. (\%) & 2 & $(1.5)$ & 1 & $(0.7)$ & $>0.99$ \\
Other & 2 & $(1.5)$ & 6 & $(4.7)$ & 0.28 \\
\hline
\end{tabular}

*Localized axillary swelling or tenderness ipsilateral to the vaccination arm 
Table 3. Duration of AEs after the first and second doses

\begin{tabular}{|c|c|c|c|c|c|}
\hline \multirow[b]{3}{*}{ Pain } & \multicolumn{5}{|c|}{ Duration of AEs in days } \\
\hline & \multicolumn{2}{|c|}{$\begin{array}{c}\text { First dose } \\
\text { mean }( \pm \mathrm{SD})\end{array}$} & \multicolumn{2}{|c|}{$\begin{array}{l}\text { Second dose } \\
\text { mean }( \pm S D)\end{array}$} & \multirow{2}{*}{$\begin{array}{r}\text { p value } \\
0.28\end{array}$} \\
\hline & 1.96 & $(1.02)$ & 2.16 & (1) & \\
\hline Erythema & 1.75 & $(0.95)$ & 3 & $(1.4)$ & 0.2 \\
\hline Itching & 2 & $(0.81)$ & 2 & $(0.7)$ & 1 \\
\hline Swelling & 1.75 & $(0.9)$ & 2.27 & $(1.3)$ & 0.26 \\
\hline Axillary swelling/tenderness* & 1 & $(0)$ & 3.3 & $(1.2)$ & 0.07 \\
\hline Fever & 1.14 & $(0.37)$ & 1.22 & $(0.4)$ & 0.65 \\
\hline Headache & 1.33 & $(0.57)$ & 2 & $(0.5)$ & 0.10 \\
\hline Fatigue & 1.85 & $(0.86)$ & 2.03 & (1) & 0.58 \\
\hline Myalgia & 1.8 & $(0.78$ & 2.21 & (1) & 0.24 \\
\hline Arthralgia & 2 & $(0.8)$ & 2.42 & $(1.1)$ & 0.32 \\
\hline Dispnea & 2 & $(1.4)$ & 2.5 & $(2.1)$ & 0.81 \\
\hline Nausea/vomiting & 1.33 & $(0.57)$ & 1.57 & $(0.8)$ & 0.61 \\
\hline Diarrhea & 1 & $(0)$ & 2.2 & $(0.4)$ & 0.016 \\
\hline Chills & 1.75 & $(0.5)$ & 2.5 & (1) & 0.22 \\
\hline Vertigo & 1.5 & $(0.7)$ & 3 & & 0.33 \\
\hline
\end{tabular}

*Localized axillary swelling or tenderness ipsilateral to the vaccination arm. 
medRxiv preprint doi: https://doi.org/10.1101/2021.11.21.21266561; this version posted January 5, 2022. The copyright holder for this preprint (which was not certified by peer review) is the author/funder, who has granted medRxiv a license to display the preprint in perpetuity.

All rights reserved. No reuse allowed without permission.

\section{Legend}

Figure 1 Rate of AEs after the first (A) and second dose (B) of mRNA-1273 vaccine

Figure 2. Patients who experienced AEs after the first and second dose

Figure 3 Patients stratified according to age who experienced AEs after the first (A) and second dose (B) 
medRxiv preprint doi: https://doi.org/10.1101/2021.11.21.21266561; this version posted January 5, 2022. The copyright holder for this preprint (which was not certified by peer review) is the author/funder, who has granted medRxiv a license to display the preprint in perpetuity.

All rights reserved. No reuse allowed without permission. 
Adverse effects after the first dose

है

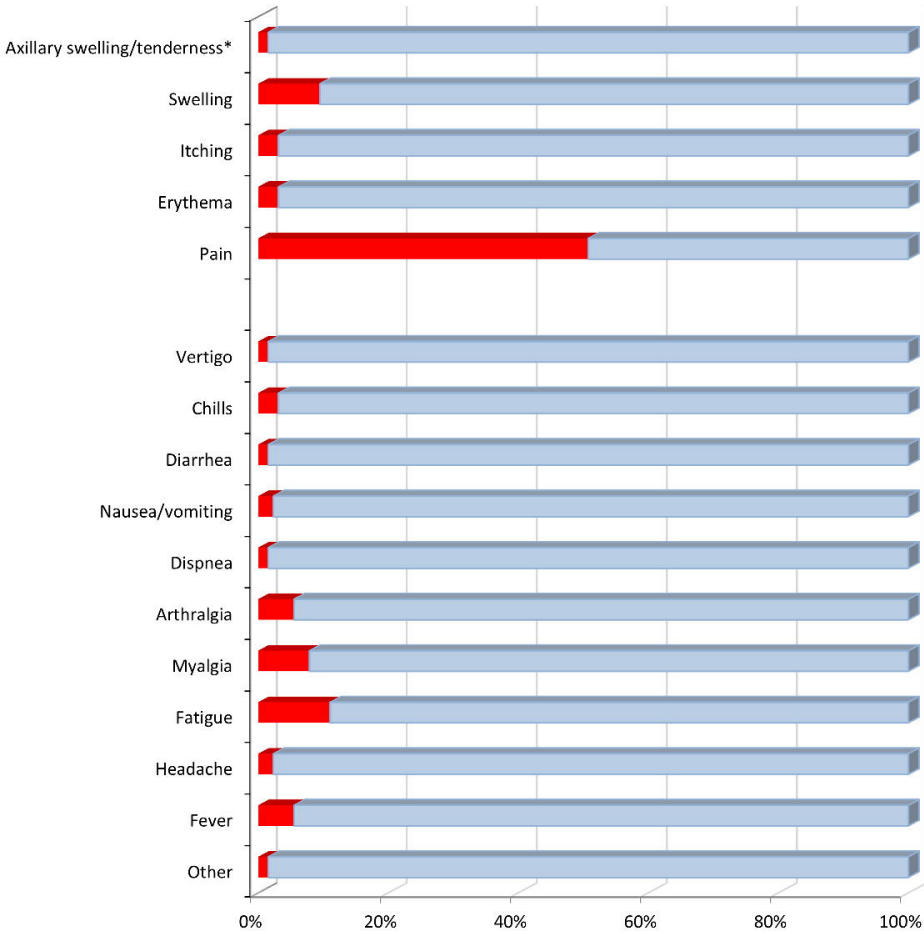

Yes

No

Rate of events 


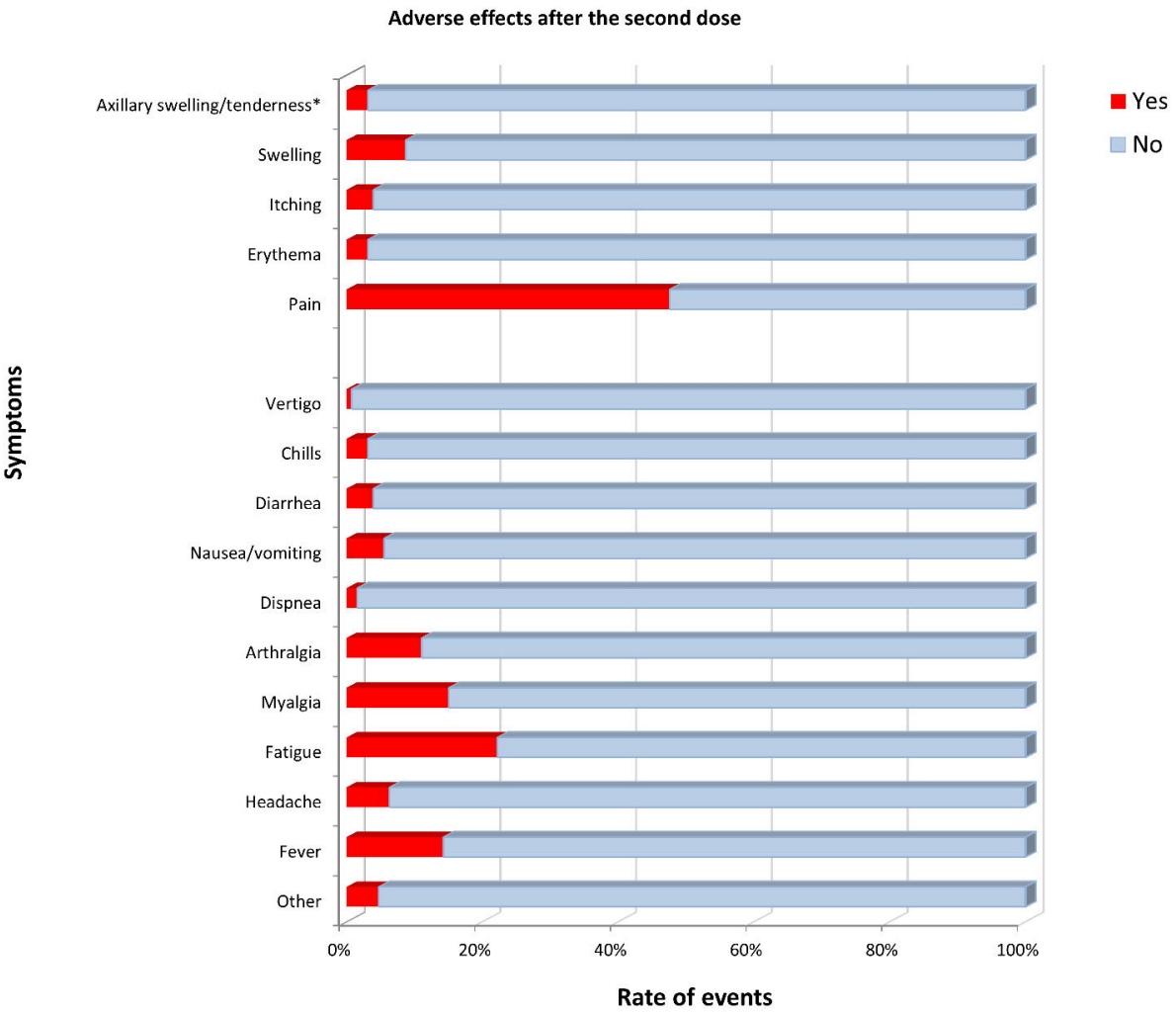




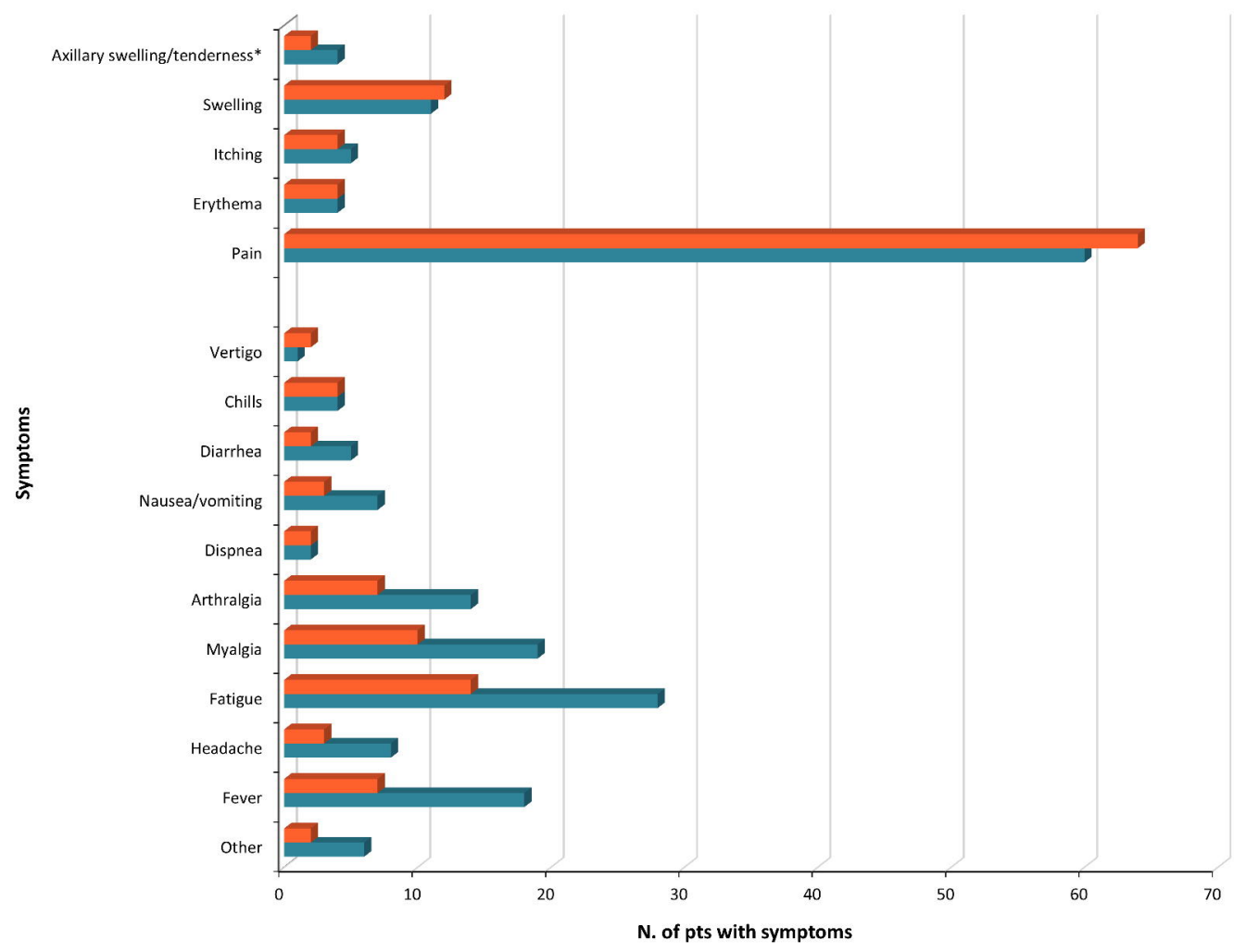

First dose

- Second dose 
Adverse effects after first dose

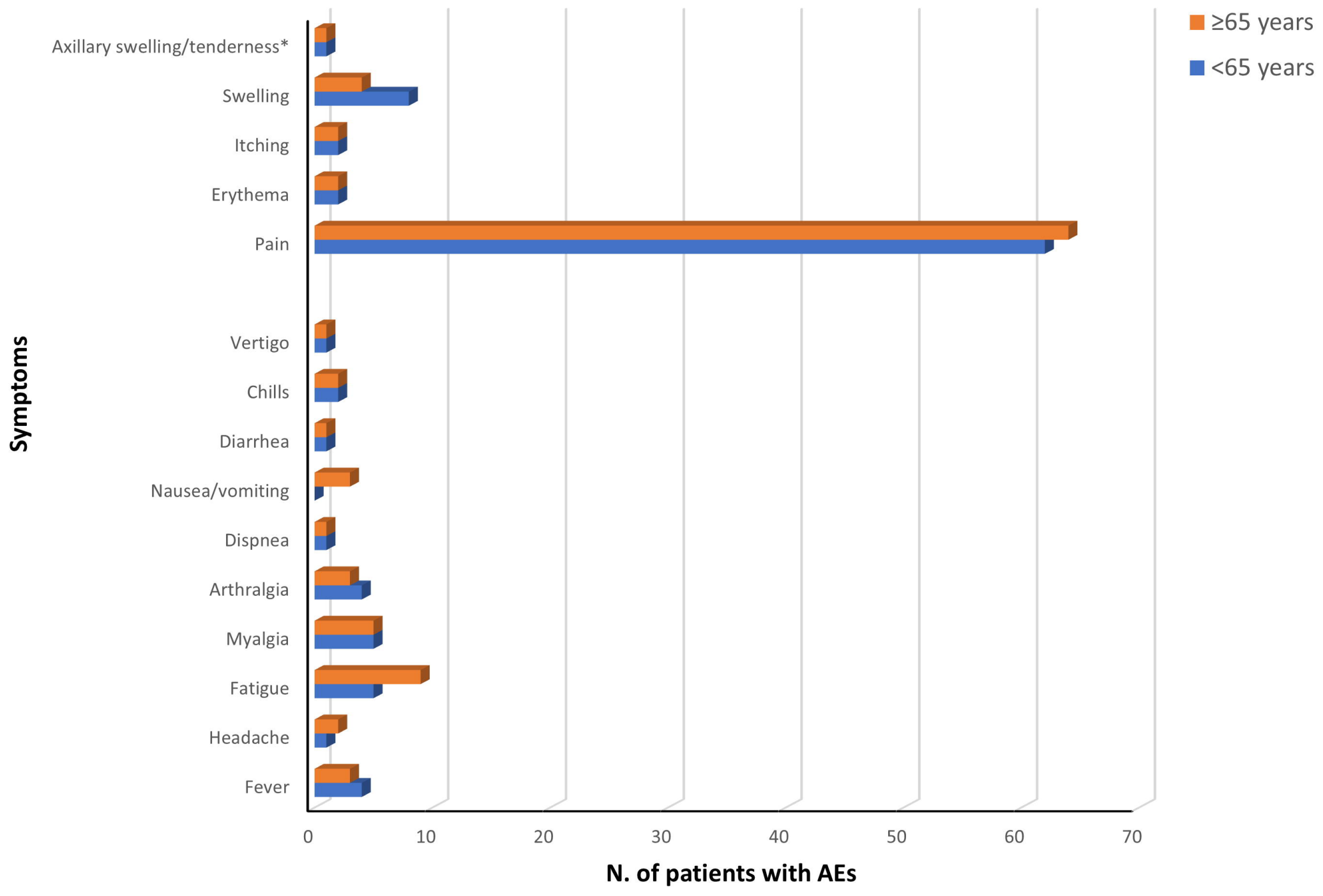




\section{Adverse effects after second dose}

है

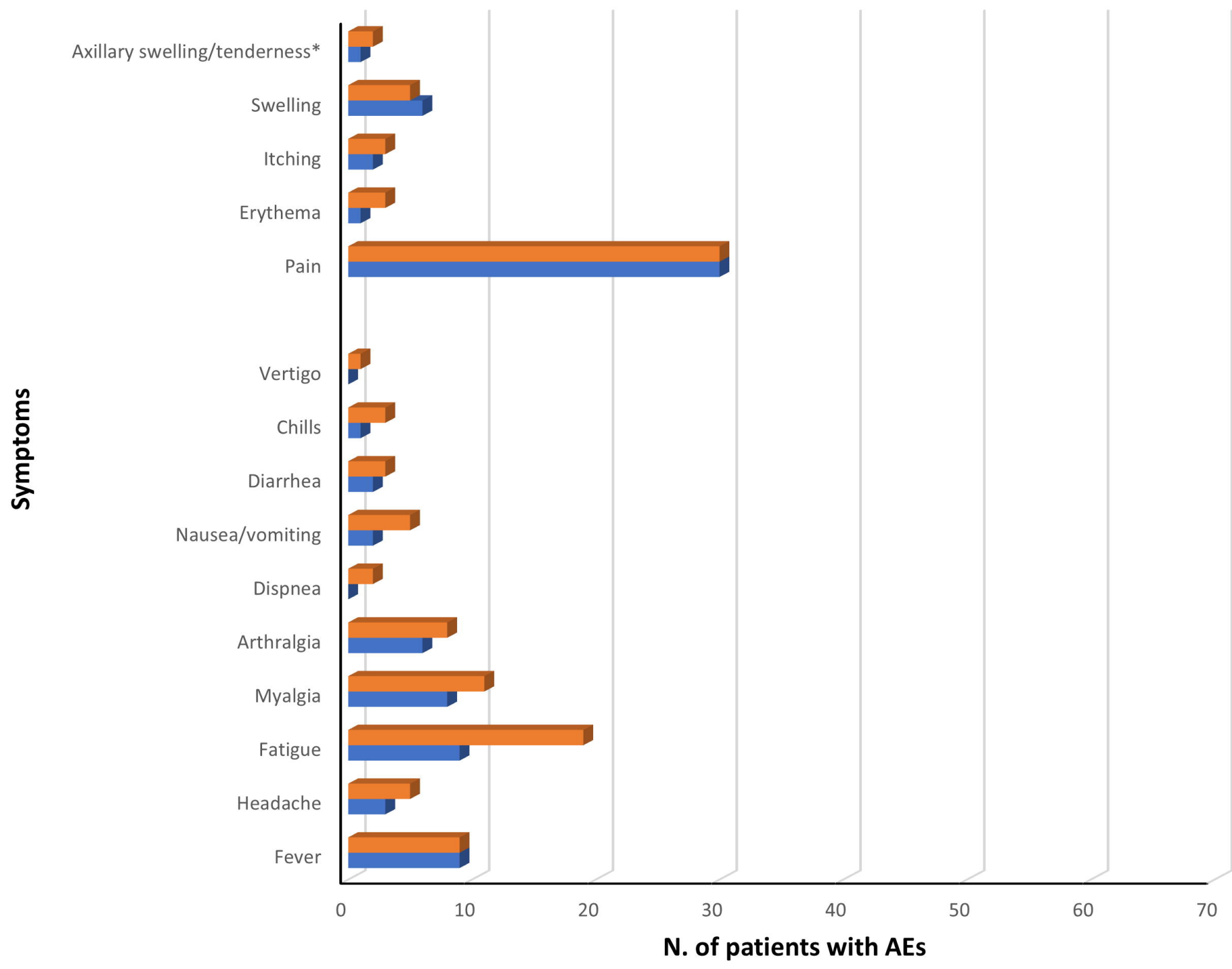

$\geq 65$ years

$<65$ years 